\title{
Myelin-Associated Glycoprotein
}

National Cancer Institute

\section{Source}

National Cancer Institute. Myelin-Associated Glycoprotein. NCI Thesaurus. Code

C142152.

Myelin-associated glycoprotein ( $626 \mathrm{aa}, \sim 69 \mathrm{kDa}$ ) is encoded by the human MAG gene.

This protein plays a role in the maintenance of axon myelination. 